\title{
Diagnosis and Incidence of Spondylosis and Cervical Disc Disorders in the University Clinical Hospital in Olsztyn, in Years 2011-2015
}

\author{
Małgorzata Kolenkiewicz $\left(\mathbb{D},{ }^{1}\right.$ Andrzej Włodarczyk, ${ }^{2}$ and Joanna Wojtkiewicz ${ }^{1}$ \\ ${ }^{1}$ Department of Pathophysiology, School of Medicine, Collegium Medicum, University of Warmia and Mazury in Olsztyn, \\ Olsztyn, Poland \\ ${ }^{2}$ Department of Public Health, Epidemiology and Microbiology, School of Medicine, Collegium Medicum, University of Warmia and \\ Mazury in Olsztyn, University Clinical Hospital in Olsztyn, Olsztyn, Poland \\ Correspondence should be addressed to Małgorzata Kolenkiewicz; malgorzata.kolenkiewicz@uwm.edu.pl
}

Received 31 July 2017; Accepted 15 February 2018; Published 25 March 2018

Academic Editor: Vida Demarin

Copyright (C) 2018 Małgorzata Kolenkiewicz et al. This is an open access article distributed under the Creative Commons Attribution License, which permits unrestricted use, distribution, and reproduction in any medium, provided the original work is properly cited.

\begin{abstract}
Background. Disorders connected with the musculoskeletal and central nervous system dysfunction are the most significant clinical problem worldwide. Our earlier research has shown that back and spinal disorders and lumbar disc disorders were most frequently diagnosed using MRI scanner at the University Clinical Hospital (UCH) in Olsztyn in years 2011-2015. We have also observed that another two diseases of spinal column, spondylosis and cervical disc disorders, were also very prevalent. The main objective of this work was to analyze the prevalence of spondylosis and cervical disc disorders in the study population diagnosed at UCH in years 2011-2015. Methods. The digital database including patients' diagnostic and demographic information was generated based on MRI reports from years 2011-2015 and analyzed using SPSS software. Results. Within the study group $(n=13298)$ the most frequently MRI-diagnosed diseases were musculoskeletal group (M00-M99; $n=7711 ; 57,98 \%)$ and cervical disc disorders (M50; $n=1659$; $12,47 \%)$ and spondylosis (M47, $n=611 ; 4,59 \%)$. More women $(67 \%)$ than men $(33 \%)$ were enrolled in the study, and the largest fraction of the study population was in the range of 51-60 years, with about $1 / 3$ of cases of both diseases diagnosed in early age range of 31-40 years. Conclusion. Significant number of patients presenting with either of the spine disorders at the young age of 31-40 years points to the necessity of introducing methods preventing disorders of the vertebral column at younger age, preferably at school age.
\end{abstract}

\section{Introduction}

Spinal disorders become an increasingly important social and medical problem of the modern world. The back pain can result from various pathologies and in $90 \%$ of patients, among the main causes are damage and degenerative changes in the intervertebral discs or spondyloarthrosis [1-4]. Our earlier study has shown that in the Warmia and Mazury Province the most common musculoskeletal disorders were different types of back diseases, and among them, intervertebral disc disorders were most prominent ([5]-ibid), which was in agreement with reports from other populations [611]. Spondylosis and cervical disc disorders however are also very frequent diseases of spinal column, as was earlier documented [2-4].
Spondyloses occur predominantly in the lumbar part, mainly due to an unfavorable ratio of the mechanical load-usually excessive-to the size of the intervertebral discs [12]. Lumbar spondyloses (LS) are characterized by degenerative changes in the spine, intervertebral disc or facet joints, vertebral body sclerosis, and hypertrophy of spinal column ligaments and others. Moreover, negative functional effects of LS may lead to the loss of spinal mobility [2]. However, spondyloses may occur also in the cervical part of vertebral column and they can be divided into the traumatic and nontraumatic injuries. Traumatic injuries occur mainly during frontal impact, such as a "whiplash" occurring during car accidents [13]. Intervertebral disc herniation and pathological changes in the vertebra as related to age, sex, 
TABLE 1: Percentage of M category diseases among all spinal diseases.

\begin{tabular}{lcccccc}
\hline Percentage of disease codes [\%] & 2011 & 2012 & 2013 & 2014 & 2015 & $2011-2015$ \\
\hline M40 & 0 & 0,00 & 0,00 & 0,13 & 0,07 & 0,05 \\
M41 & 0,14 & 0,04 & 0,17 & 0,16 & 0,18 & 0,14 \\
M42 & 0,16 & 0,04 & 0,03 & 0,03 & 0,00 & 0,04 \\
M43 & 0,07 & 0,09 & 0,03 & 0,03 & 0,05 \\
M45 & 0,00 & 0,00 & 0,00 & 0,06 & 0,11 & 0,00 \\
M46 & 0,00 & 0,04 & 0,03 & 0,00 & 6,04 \\
M47 & 3,81 & 3,29 & 3,74 & 5,38 & 0,02 \\
M48 & 0,00 & 0,00 & 0,48 & 1,34 & 0,77 & 0,00 \\
M49 & 0,14 & 0,00 & 0,00 & 0,00 & 0,61 \\
M50 & 10,88 & 11,11 & 13,58 & 14,40 & 10,92 & 0,02 \\
M51 & 28,90 & 38,85 & 25,72 & 30,33 & $\mathbf{4}$ & 31,73 \\
\hline
\end{tabular}

occupation, and life style belong to the group of nontraumatic injuries [14]. Most of the pathological changes in spondyloses are combination of factors, such as decrease of the disc height or degenerative changes in the joints [15].

Problems in cervical part of spinal column are also connected with neck, arm, and forearm pain, which can significantly decrease the quality of life; this is due to pathological changes impacting cervical spinal nerves forming cervical and brachial plexuses [14]. The neck and shoulder pain are found to be more common disorders than the low back pain [16]; each of them is often connected to specific professions [16-24].

Here we describe the population presenting with spinal and back injuries focusing on spondylosis and cervical disc disorders, diagnosed using MRI at the University Clinical Hospital in Olsztyn, in years 2011-2015.

\section{Materials and Methods}

The prevalence of spondylosis and cervical disc disorders using the digital database of patients is examined by MRI at the University Clinical Hospital (UCH) in Olsztyn. The database included all MRI scans collected in years 2011-2015, age, sex, and the diagnosis. All disease categories were recorded using an appropriate letter code according to the International Statistical Classification of Diseases and Related Health Problems, Tenth Revision (ICD-10) [25]. For further analyses, data of patients presenting with the specific diseases of musculoskeletal system and connective tissue including spondylosis (M47) and cervical disc disorders (M50) were selected and grouped into the given disease subtypes. Sex distribution in each study subtype and in each year of the study was determined, and to identify the age group most frequently diagnosed, study population was divided into ten age groups in the 10-year intervals.

\section{Results}

During five years of the study period, among all spinal diseases diagnosed at the UCH, M47 (spondylosis) and M50 (cervical disc disorders) represented above $4 \%$ and $12 \%$, respectively (Table 1). In each of those general groups, specific subtypes were defined, and two biggest subtypes of each group were chosen for detailed analyses.

Spondylosis was diagnosed in $n=608$ cases, and more than half of them, $n=432$ cases, belonged to the general category defined by the code M47. Small number of spondylosis cases were defined by more specific codes (see below and in Table 2), and the most numerous subtypes belonged to the M47.2 code, defining "other spondylosis with radiculopathy," $n=80$, and M47.8 code, defining "other spondylosis including cervical spondylosis, lumbosacral spondylosis and thoracic spondylosis," $n=92$. Number of M47 cases gradually increased in years 2011-2014, but their slight decrease in 2015 was observed. The cases classified as M47.2 and M47.8 were diagnosed for the first time in 2013, and these two subtypes presented different frequency distribution pattern. M47.2 dramatically increased in 2015 whereas number of M47.8 cases decreased at the same time. The other subtypes constituting also less populous groups appeared for the first time in 2013, and numbers of patients in these subgroups were similar and relatively constant in the following years ( $n$ $=1-3$; Table 2). All analyzed disease subtypes were more often diagnosed in the female $(>60 \%)$ than in the male subjects (Tables 3 and 4), and most diagnoses of both female and male patients occurred in the age group of 51-60 years (Figure 1).

Cervical disc disorders were diagnosed in $n=1659$ cases during the entire study period, and the vast majority of them, $n=1344$, were defined by the general code M50. Within this group, most numerous subtypes were M50.1, defining cervical disc disorder with radiculopathy represented by $n=116$ cases, and M50.2 including other cervical disc displacements represented by $n=119$ cases. M50 cases were gradually increasing in numbers in years 2011-2013 and then started to drop in years 2014-2015. Moreover, cases classified as M50.1 and M50.2 were recorded for the first time in 2013, and these two subtypes had a different frequency distribution patterns: M50.1 cases increased in numbers in years 2013-2014 and then decreased in 2015, whereas in the same time period the number of M50.2 cases was steadily raising. The other and more sporadic disease groups were for the first time reported in 2013, and the number of these rare cases increased in 2014 and was at similar level in $2015(n=30-40$; Table 2$)$. The reports available to us did not contain detailed information 
TABLE 2: Number of M47 and M50 categories diseases.

\begin{tabular}{|c|c|c|c|c|c|c|}
\hline $\begin{array}{l}\text { Types of category M } \\
\text { diseases }\end{array}$ & 2011 & 2012 & 2013 & 2014 & 2015 & 2011-2015 \\
\hline \multicolumn{7}{|c|}{ M47 } \\
\hline M47 & 55 & 77 & 85 & 112 & 103 & 432 \\
\hline M47.2 & 0 & 0 & 4 & 11 & 65 & 80 \\
\hline M47.8 & 0 & 0 & 40 & 46 & 6 & 92 \\
\hline Others of M47 & 0 & 0 & 3 & 3 & 1 & 7 \\
\hline Total of M47 & 55 & 77 & 132 & 172 & 176 & 611 \\
\hline \multicolumn{7}{|c|}{ M50 } \\
\hline M50 & 157 & 260 & 448 & 322 & 157 & 1344 \\
\hline M50.1 & 0 & 0 & 23 & 55 & 38 & 116 \\
\hline M50.2 & 0 & 0 & 6 & 40 & 73 & 119 \\
\hline Others of M50 & 0 & 0 & 2 & 40 & 38 & 80 \\
\hline Total of M50 & 157 & 260 & 479 & 452 & 311 & 1659 \\
\hline
\end{tabular}

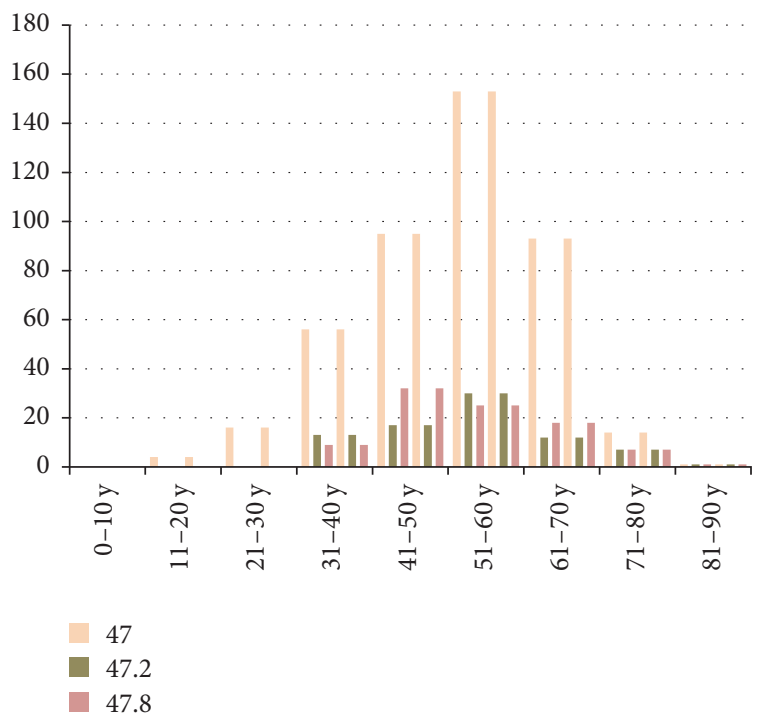

FIgURE 1: Number of spondylosis MRI scans in ten age ranges, 2011-2015.

about the localization of the neck pain. All analyzed M50 subtypes were more often found in the female than in the male patients, female patients accounting for more than $60 \%$ (Tables 3 and 4). In both sexes the most frequently diagnosed patients were in the age group of 51-60 years (Figure 2).

\section{Discussion}

Here we have shown that the cervical disc disorders in the general category M50 were the second most common type of musculoskeletal disorders diagnosed by magnetic resonance imaging tests in the Warmia and Mazury Province in years 2011-2015, following intervertebral disc disorders in the M51 disease category we have described elsewhere [5]. Two subtype codes including M50.1, cervical disc disorder with radiculopathy, and M50.2, other cervical disc displacement,

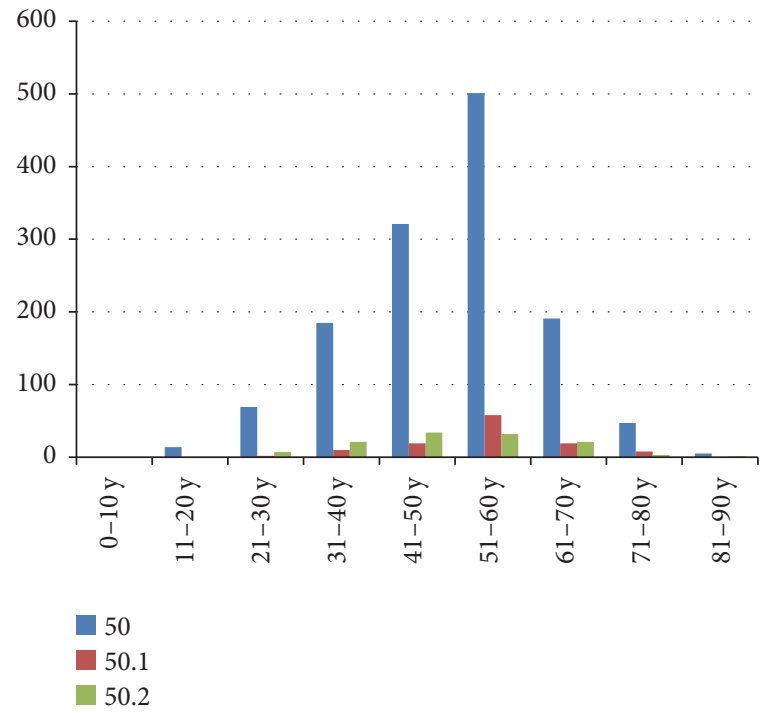

FIgURE 2: Number of cervical disc disorders MRI scans in ten age ranges, 2011-2015.

were reported in years 2013-2015. The third group of musculoskeletal disorders diagnosed with the MRI were spondylosis M47 cases, although they were less frequently reported compared to the M51 and M50 disease categories. Within the general M47 category of spondyloses, cases of spondylosis with radiculopathy defined by M47.2 and other spondylosis including cervical spondylosis, lumbosacral spondylosis, and thoracic spondylosis defined by M47.8 codes were also reported. Interestingly, common features of all three general spinal disease groups included diagnoses more frequent in the female $(>60 \%)$ than in the male subjects and in the age group of 51-60 years.

The neck problems are usually the first symptoms of the cervical disorders and the reason for the detailed radiological examination. The symptoms of neck problems have been very often described by patients such as severe neck pain radiating 


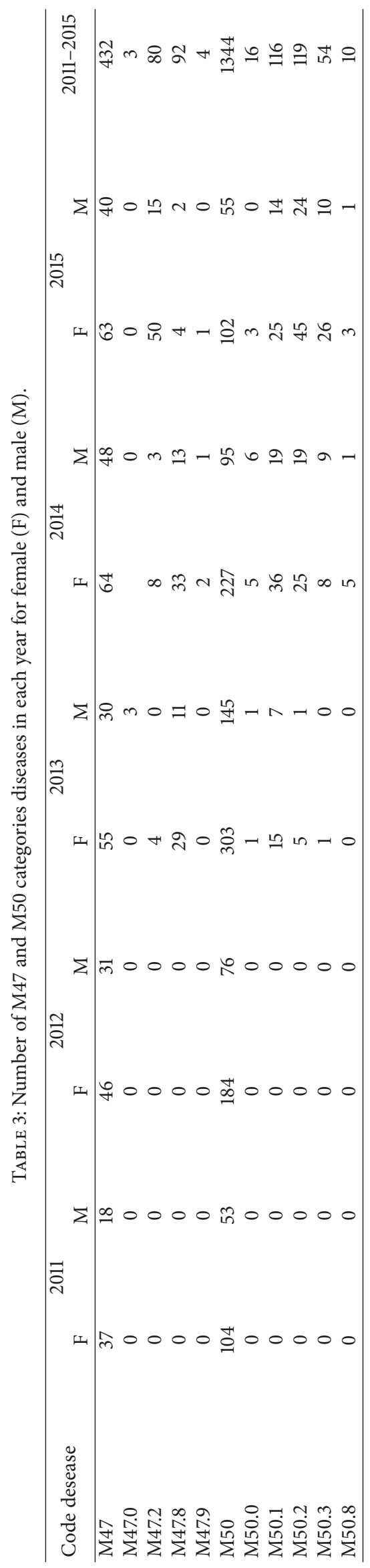


TABLE 4: The pattern of percentage of female (F) and male (M) in analyzed diseases in the most numerous subtypes of patients of 51-60-year age range.

\begin{tabular}{lcccccccccc}
\hline & & 2011 & \multicolumn{2}{c}{2012} & \multicolumn{2}{c}{2013} & \multicolumn{2}{c}{2014} & & \\
& F & M & F & M & F & M & F & M & F \\
\hline M47 & 69,09 & 30,91 & 61,04 & 38,96 & 65,88 & 34,12 & 58,04 & 41,96 & 61,17 & 38,83 \\
M47.2 & 0 & 0 & 0 & 0 & 75,00 & 25,00 & 72,73 & 27,27 & 46,15 & 53,85 \\
M47.8 & 0 & 0 & 0 & 0 & 75,00 & 25,00 & 71,74 & 28,26 & 66,67 & 33,33 \\
M50 & 67,52 & 32.48 & 69,62 & 30,38 & 67,86 & 32,14 & 71,12 & 28,88 & 68,79 & 31,21 \\
M50.1 & 0 & 0 & 0 & 0 & 65,22 & 34,78 & 65,45 & 34,55 & 63,16 & 36,84 \\
M50.2 & 0 & 0 & 0 & 0 & 83,33 & 11,67 & 65,00 & 35,00 & 63,01 & 36,99 \\
\hline
\end{tabular}

to the shoulder and upper limb. Neurologic status of those patients was usually characterized by motor and sensory loss in different parts of arm and forearm $[14,26]$. Unfortunately, there were no details about the localization of the neck pain in our study population.

Cases of spinal injuries occurring during the road accidents are frequently reported in the literature, and from $30 \%$ to $75 \%$ of these cases are related to the cervical injures [27-35]. Some researches have shown that during traumatic and nontraumatic accidents the fractures or dislocation of vertebrae or damage of soft tissue including the spinal cord was usually found at C4-C8 level [28, 29, 31, 33, 36, 37] and low intervertebral disc levels were more exposed to damage because of their size [38]. Earliest studies have shown that there was a wide age range of patients with various kinds of cervical injures, but the largest numbers of cases were between 31 and 59 years [27, 28, 31, 33, 34]. Moreover, reported cervical injury cases related mainly to man rather than woman $[27,31,32,39]$.

The cases of cervical radiculopathy are rare and perhaps therefore rarely reported; in our study there was also only a small fraction of a study group. The radiculopathy in Minnesota population prevalence was 107.3 for men and 63.5 for women (per 100,000 population) and it was the highest at the age of 50-54 years [15]. The most common cause of cervical radiculopathy is due to a combination of factors such as decreased disc height and degenerative changes of vertebral column joints and herniation of the nucleus pulposus of intervertebral disc $[14,15,30]$.

Some researches have found that cervical vertebra can be injured by frontal or rear impacts during vehicle accidents or during sports and game activities [27-32]. Injuries of cervical vertebra may then result in damage to intervertebral discs including disk displacement and/or compression on the spinal nerve roots [13]. Additionally, it has been shown that each intervertebral level of cervical disc tissue had a different limit for physiological and impact challenge. The C2-C3 middle disc annular tissue was found to be the most sensitive, and it was destroyed at the muscle force replication of $6 \mathrm{~g}$, whereas C3-C4 and C5-C6 discs were damaged at muscle force replication of $10 \mathrm{~g}$ [13]. Studies on Minnesota patients population with cervical radiculopathy have shown that the most frequent was monoradiculopathy involving C7 and C6 nerve roots and only in 14\% of all cases physical exertion or trauma has occurred [15]. This suggests that in the vertebral cervical section radiculopathy can partly be caused by other factors like spondylosis.

An annual incidence rate of cervical spondylotic radiculopathy varies greatly between populations. For example, in Sicilian population it was 3.5 per 1000 being highest at the age of 50-59 years [40], whereas in the USA 30\% and in Ethiopia $9 \%$ of all hospitalized patients have shown nontraumatic cervical spondylosis $[39,41]$.

Most of spondylosis cases were connected with the lumbar part of vertebral column (lumbar spondylosis) and they presented degenerative changes in the lumbar spine [2-4]. In the USA lumbar spondylosis was one of the fastest growing reasons for spinal surgery in adults [42]. The spondylosis surgery is usually performed in either of the two ways: discectomy or chemonucleolysis. The meta-analysis data of surgical cases have demonstrated that patients had better clinical outcomes following discectomy than after chemonucleolysis, and discectomy was much more effective in treating of sciatica patients [4]. According to the same meta-analysis data, in the 80 s and 90 s of 20 th century spondylosis occurred more often in man than woman regardless of the age ranges [4]. Nowadays, the same situation was observed in the Japanese population, where the spondylosis was more frequent in man than in woman, and the age was the strongest among many factors associated with the disease $[3,43]$.

The group of spondyloses contains also arthrosis or osteoarthritis of spine degeneration of facet joints. Some studies have shown that MRI can precisely visualize facet joint osteoarthritis [42-44]. Studies on the cervical and lumbar facet joins have shown that the thickness and width of joint cartilage depended on the region of spine, sex, and location [42-44]. Moreover, changes in tissue structure due to osteoarthritis are thought to be strongly connected with disc degeneration, and in adult facet joint osteoarthritis, the disease follows the onset of disc degeneration [43].

Conclusion. Our study shows that while the largest fraction of patients suffering from any of the spine disorders is in the 51-60-year age group, a significant number of patients first present with these diseases at much younger age of 31-40 years in the Warmia and Mazury Province. This observation points to an urgency of developing and introducing methods preventing disorders of the vertebral column at a younger age, preferably at a school age. Additionally, this study also demonstrates the significance of access to MRI as a method of 
choice in early and reliable diagnosis of pathological changes in the spinal column.

\section{Disclosure}

The funders had no role in study design, data collection and analysis, decision of publication, or preparation of the manuscript.

\section{Conflicts of Interest}

The authors declare that there are no conflicts of interest regarding the publication of this paper.

\section{Authors' Contributions}

All authors have read and approved the final manuscript.

\section{Acknowledgments}

This research was supported by the European Union [Funds no. POPW.01.03.00-28.014/09-00].

\section{References}

[1] S. D. Early, R. M. Kay, and V. T. Tolo, "Childhood Diskitis," Journal of the American Academy of Orthopaedic Surgeons, vol. 11, no. 6, pp. 413-420, 2003.

[2] D. Chiba, K. Wada, T. Tanaka et al., "Serum pentosidine concentration is associated with radiographic severity of lumbar spondylosis in a general Japanese population," Journal of Bone and Mineral Metabolism, vol. 35, no. 1, pp. 65-72, 2017.

[3] J. N. A. Gibson and G. Waddell, "Surgery for degenerative lumbar spondylosis: updated Cochrane Review," The Spine Journal, vol. 30, no. 20, pp. 2312-2320, 2005.

[4] J. N. A. Gibson, I. C. Grant, and G. Waddell, "The Cochrane review of surgery for lumbar disc prolapse and degenerative lumbar spondylosis," The Spine Journal, vol. 24, no. 17, pp. 1820$1832,1999$.

[5] M. Kolenkiewicz and J. Wojtkiewicz, "Trends in the utilization of advanced diagnostic imaging and lumbar disc disorders diagnosis in the warmia and mazury province, Poland," Poland. J Pol Ann Med., 2018.

[6] K. Rapala, A. Brychcy, and A. Truszczynska, "Obraz rezonansu magnetycznego kręgosłupa lędźwiowego - bezobjawowy klinicznie - u kandydatów na pilotów samolotów wojskowych [NMR scan of the lumbar spine - clinically asymptomatic- in candidates for pilots of the military aircrafts]," The Polish Journal of Aviation Medicine, Bioengineering and Psychology, vol. 3, pp. 241-249, 2011.

[7] K. M. C. Cheung, J. Karppinen, D. Chan et al., "Prevalence and pattern of lumbar magnetic resonance imaging changes in a population study of one thousand forty-three individuals," The Spine Journal, vol. 34, no. 9, pp. 934-940, 2009.

[8] P. Suthar, R. Patel, C. Mehta, and N. Patel, "MRI evaluation of lumbar disc degenerative disease," Journal of Clinical and Diagnostic Research, vol. 9, no. 4, pp. TC04-TC09, 2015.

[9] W. Kulak and D. Kondzior, "Dyskopatia kręgosłupa odcinka lędźwiowo-krzyżowego w korelacji z natężeniem bólu, depresją $\mathrm{i}$ akceptacją choroby [Discopathy of the lumbar spine in relation to intensity of pain, depression and illness acceptance]," Problemy Higieny i Epidemiologii, vol. 91, pp. 153-157, 2010.
[10] R. Jankowski, T. Blok, R. Piestrzeniewicz, R. Zukiel, R. Czekanowska-Szlandrwoicz, and J. Moskal, "Wskazania do operacji i wyniki leczenia przepukliny krążka międzykręgowego w odcinku lędźwiowo-krzyżowym kręgosłupa [Indication nad results of sugrical teratment of lumbo-sacral disc herniation]," Neuroskop, vol. 1, pp. 43-50, 2003.

[11] J. Paprocka, E. Jamroz, E. Gruszkiewicz, A. Klimczak, E. Kluczewska, and E. Marszal, "Zespoły bólowe kręgosłupa u dzieci," Wiadomości Lekarskie, vol. 61, pp. 7-9, 2008.

[12] M. A. Adams and P. J. Roughley, "What is intervertebral disc degeneration, and what causes it?" The Spine Journal, vol. 31, no. 18, pp. 2151-2161, 2006.

[13] S. Ito, P. C. Ivancic, A. M. Pearson et al., "Cervical intervertebral disc injury during simulated frontal impact," European Spine Journal, vol. 14, no. 4, pp. 356-365, 2005.

[14] J. S. Saal, J. A. Saal, and E. F. Yurth, "Nonoperative management of herniated cervical intervertebral disc with radiculopathy," The Spine Journal, vol. 21, no. 16, pp. 1877-1883, 1996.

[15] K. Radhakrishnan, W. J. Litchy, W. M. O'Fallon, and L. T. Kurland, "Epidemiology of cervical radiculopathy: a populationbased study from Rochester, Minnesota, 1976 through 1990," Brain, vol. 117, no. 2, pp. 325-335, 1994.

[16] L. L. Andersen, T. Clausen, O. S. Mortensen, H. Burr, and A. Holtermann, "A prospective cohort study on musculoskeletal risk factors for long-term sickness absence among healthcare workers in eldercare," International Archives of Occupational and Environmental Health, vol. 85, no. 6, pp. 615-622, 2012.

[17] Y. Salik and A. Özcan, "Work-related musculoskeletal disorders: a survey of physical therapists in Izmir-Turkey," BMC Musculoskeletal Disorders, vol. 5, article 27, 2004.

[18] B. O. A. Adegoke, A. K. Akodu, and A. L. Oyeyemi, "Workrelated musculoskeletal disorders among Nigerian Physiotherapists," BMC Musculoskeletal Disorders, vol. 9, no. 1, article 112, 2008.

[19] H. N. Alrowayeh, T. A. Alshatti, S. H. Aljadi, M. Fares, M. M. Alshamire, and S. S. Alwazan, "Prevalence, characteristics, and impacts of work-related musculoskeletal disorders: A survey among physical therapists in the State of Kuwait," BMC Musculoskeletal Disorders, vol. 11, article no. 116, 2010.

[20] B. M. Tinubu, C. E. Mbada, A. L. Oyeyemi, and A. A. Fabunmi, "Work-related musculoskeletal disorders among nurses in Ibadan, South-west Nigeria: a cross-sectional survey," BMC Musculoskeletal Disorders, vol. 11, article 12, 2010.

[21] E. C. Alexopoulos, I.-C. Stathi, and F. Charizani, "Prevalence of musculoskeletal disorders in dentists," BMC Musculoskeletal Disorders, vol. 5, article 16, 2004.

[22] J. S. Boschman, H. F. van der Molen, J. K. Sluiter, and M. H. Frings-Dresen, "Musculoskeletal disorders among construction workers: a one-year follow-up study," BMC Musculoskeletal Disorders, vol. 13, article 196, 2012.

[23] E. C. Alexopoulos, D. Tanagra, E. Konstantinou, and A. Burdorf, "Musculoskeletal disorders in shipyard industry: Prevalence, health care use, and absenteeism," BMC Musculoskeletal Disorders, vol. 7, article no. 88, 2006.

[24] M. D. Antonopoulou, A. K. Alegakis, A. G. Hadjipavlou, and C. D. Lionis, "Studying the association between musculoskeletal disorders, quality of life and mental health. A primary care pilot study in rural Crete, Greece," BMC Musculoskeletal Disorders, vol. 10, no. 1, article no. 143, 2009.

[25] International Statistical Classification of Diseases and Related Health Problems; http://apps.who.int/classifications/icd10/ browse/2016/en. 
[26] S. Carette and M. G. Fehlings, "Cervical radiculopathy," The New England Journal of Medicine, vol. 353, no. 4, pp. 392-399, 2005.

[27] F. B. Sørensen, V. Pedersen, and S. Clausen, "Epidemiology of spinal cord lesions in Denmark," Paraplegia, vol. 28, no. 2, pp. 105-118, 1990.

[28] G. E. Pickett, M. Campos-Benitez, J. L. Keller, and N. Duggal, "Epidemiology of traumatic spinal cord injury in Canada," The Spine Journal, vol. 31, no. 7, pp. 799-805, 2006.

[29] A. Soopramanien, "Epidemiology of spinal injuries in romania," Paraplegia, vol. 32, no. 11, pp. 715-722, 1994.

[30] N. Draulans, C. Kiekens, E. Roels, and K. Peers, "Etiology of spinal cord injuries in Sub-Saharan Africa," Spinal Cord, vol. 49, no. 12, pp. 1148-1154, 2011.

[31] D. B. Karki, G. Gurung, K. P. Adhikary, and R. K. Ghimire, "Magnetic resonance imaging findings in degenerative disc disease of cervical spine in symptomatic patients," Journal of Nepal Health Research Council, vol. 13, no. 31, pp. 196-200, 2015.

[32] J. R. Hoffman, W. R. Mower, A. B. Wolfson, K. H. Todd, and M. I. Zucker, "Validity of a set of clinical criteria to rule out injury to the cervical spine in patients with blunt trauma," The New England Journal of Medicine, vol. 343, no. 2, pp. 94-99, 2000.

[33] R. J. O'Connor and P. C. Murray, "Review of spinal cord injuries in Ireland," Spinal Cord, vol. 44, no. 7, pp. 445-448, 2006.

[34] H. Shingu, T. Ikata, S. Katoh, and T. Akatsu, "Spinal cord injuries in Japan: A nationwide epidemiological survey in 1990," Paraplegia, vol. 32, no. 1, pp. 3-8, 1994.

[35] J. S. Krause, L. E. Broderick, and J. Broyles, "Subjective wellbeing among African-Americans with spinal cord injury: An exploratory study between men and women," Neuro Rehabilitation, vol. 19, no. 2, pp. 81-89, 2004.

[36] W. McKinley, K. Santos, M. Meade, and K. Brooke, "Incidence and outcomes of spinal cord injury clinical syndromes," The Journal of Spinal Cord Medicine, vol. 30, no. 3, pp. 215-224, 2007.

[37] A. R. Vaccaro, S. P. Falatyn, A. E. Flanders, R. A. Balderston, B. E. Northrup, and J. M. Cotler, "Magnetic resonance evaluation of the intervertebral disc, spinal ligaments, and spinal cord before and after closed traction reduction of cervical spine dislocations," The Spine Journal, vol. 24, no. 12, pp. 1210-1217, 1999.

[38] K. Pettersson, C. Hildingsson, G. Toolanen, M. Fagerlund, and J. Björnebrink, "Disc pathology after whiplash injury: A prospective magnetic resonance imaging and clinical investigation," The Spine Journal, vol. 22, no. 3, pp. 283-288, 1997.

[39] S. Pourtaheri, A. Emami, K. Sinha et al., "The role of magnetic resonance imaging in acute cervical spine fractures," The Spine Journal, vol. 14, no. 11, pp. 2546-2553, 2014.

[40] G. Salemi, G. Savettieri, F. Meneghini et al., "Prevalence of cervical spondylotic radiculopathy: A door-to-door survey in a Sicilian municipality," Acta Neurologica Scandinavica, vol. 93, no. 2-3, pp. 184-188, 1996.

[41] G. Zenebe, "Myelopathies in Ethiopia," East African Medical Journal, vol. 72, no. 1, pp. 42-45, 1995.

[42] M. A. Ciol, R. A. Deyo, E. Howell, and S. Kreif, "An assessment of surgery for spinal stenosis: Time trends, geographic variations, complications, and reoperations," Journal of the American Geriatrics Society, vol. 44, no. 3, pp. 285-290, 1996.

[43] A. Fujiwara, K. Tamai, M. Yamato et al., "The relationship between facet joint osteoarthritis and disc degeneration of the lumbar spine: an MRI study," European Spine Journal, vol. 8, no. 5, pp. 396-401, 1999.
[44] N. Yoganandan, S. A. Knowles, D. J. Maiman, and F. A. Pintar, "Anatomic study of the morphology of human cervical facet joint," The Spine Journal, vol. 28, no. 20, pp. 2317-2323, 2003. 


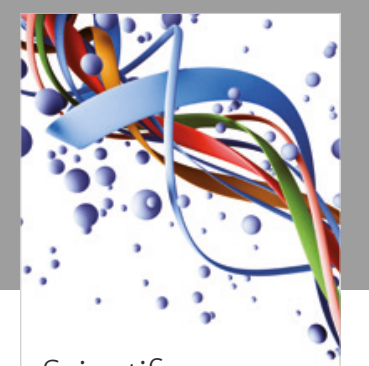

Scientifica
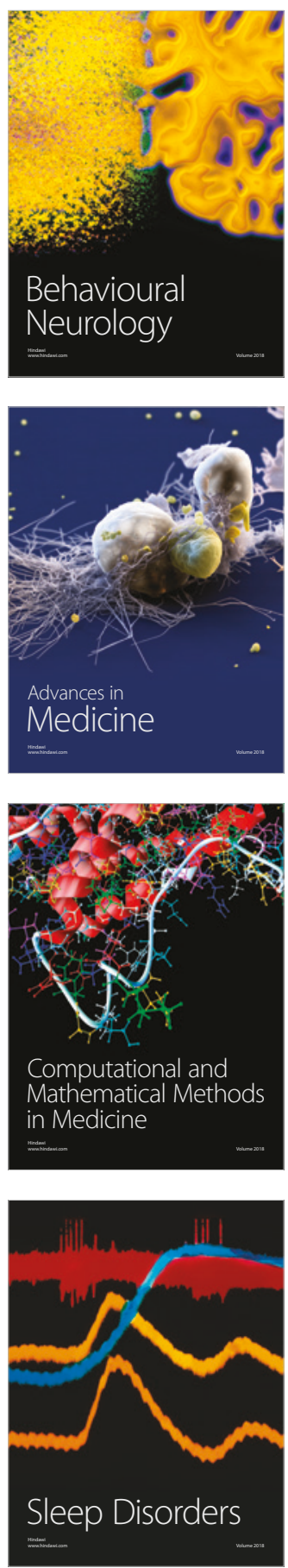

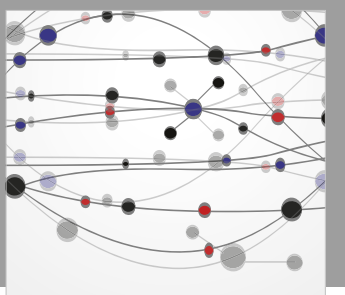

The Scientific World Journal

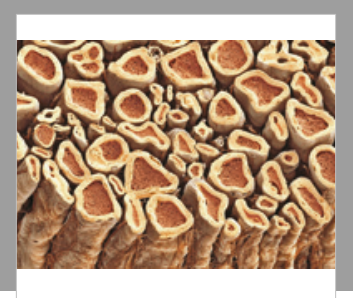

Case Reports in

Neurological Medicine

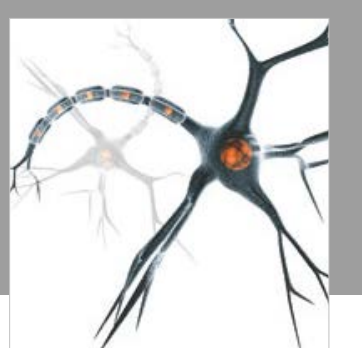

Neural Plasticity

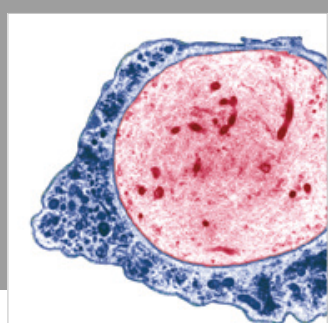

Multiple Sclerosis

International

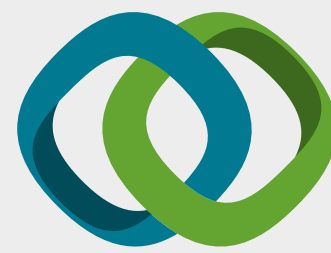

Hindawi

Submit your manuscripts at

www.hindawi.com
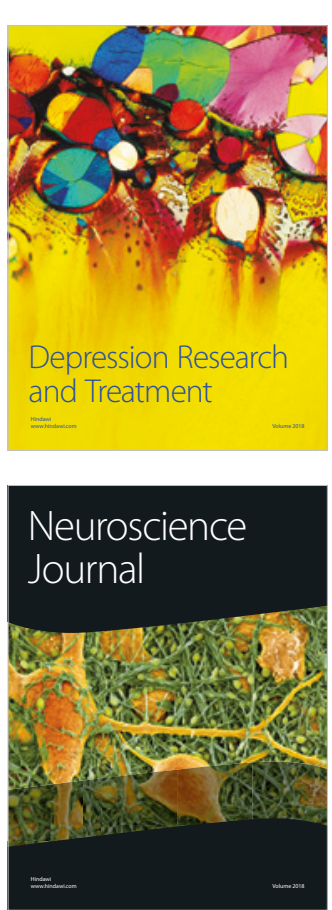

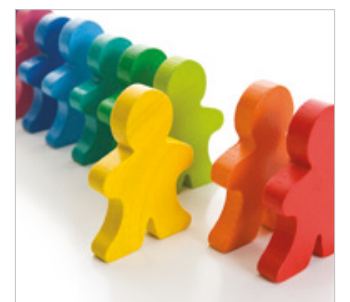

Autism

Research and Treatment
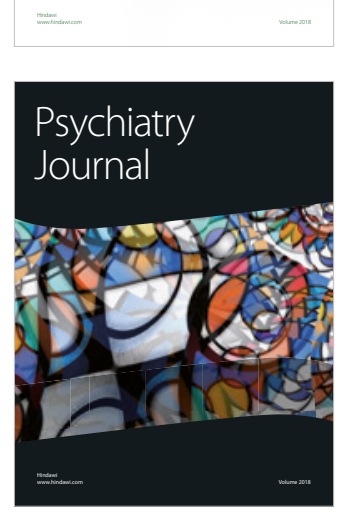
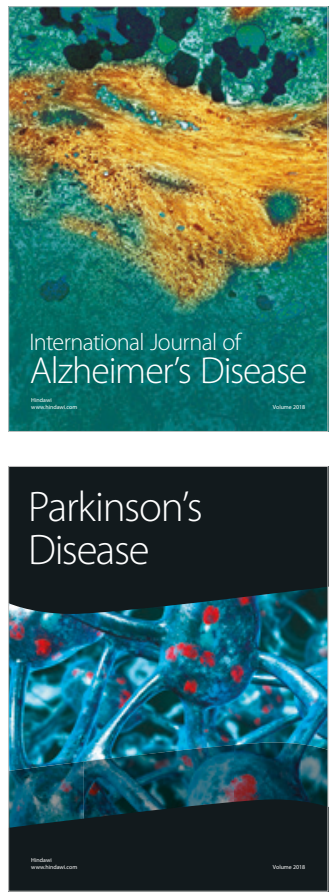
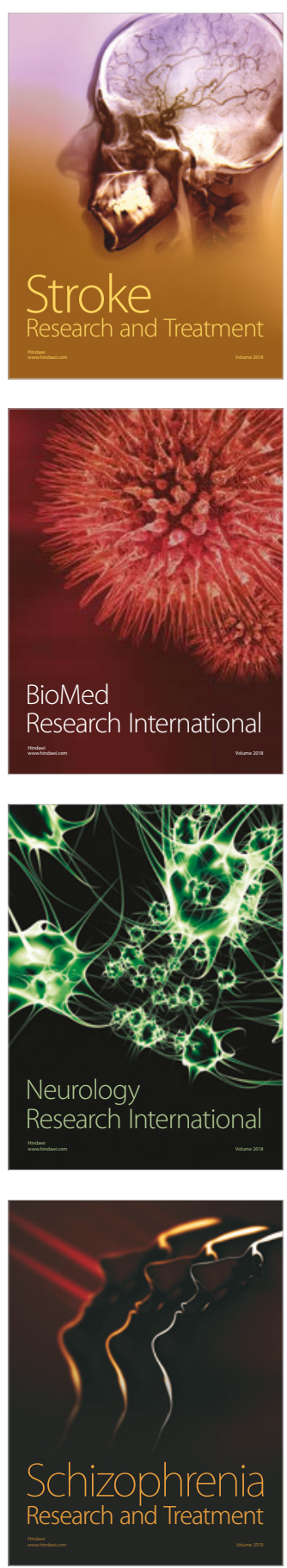